
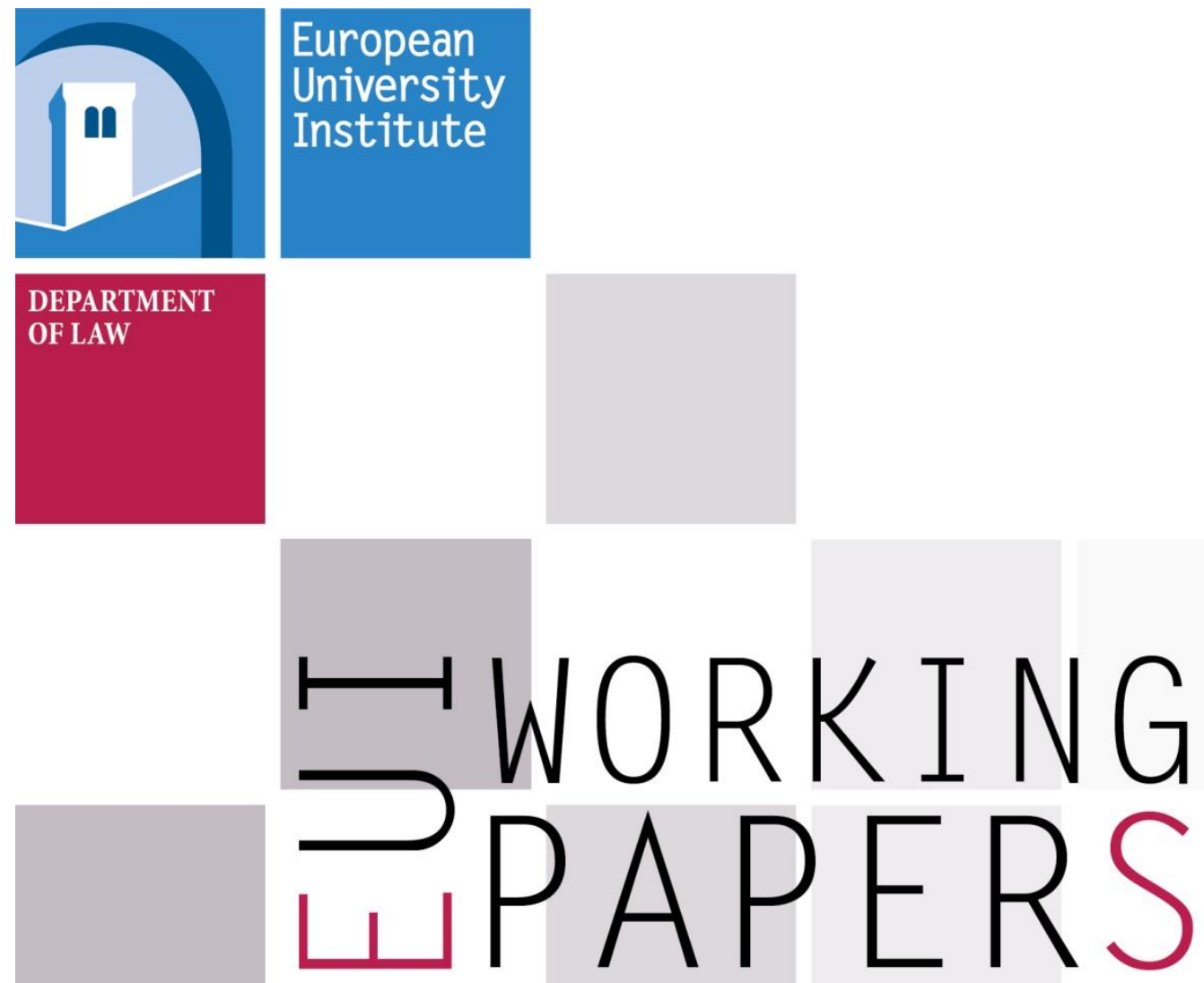

LAW 2015/05

Department of Law

European Regulatory Private Law Project (ERC-ERPL-11)

European Research Council (ERC) Grant

"I Want My Money Back" - Problems, Successes and Failures in the Price Regulation of the Gas Supply Market by Civil Law Remedies in Germany

Norbert Reich

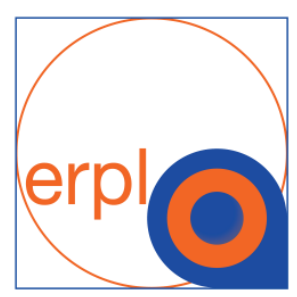



European University Institute

\section{Department of Law}

"European Regulatory Private Law" Project

European Research Council (ERC) Grant

"I Want My Money Back" - Problems, Successes and Failures in the Price Regulation of the Gas Supply MARKET BY CIVIL LAW REMEDIES IN GERMANY

Revised paper presented to the EU Energy Law and Policy Workshop "Decentralised Energy Law Enforcement", 30-31 October 2014, Florence

Norbert Reich

EUI Working Paper LAW 2015/05

ERC-ERPL-11

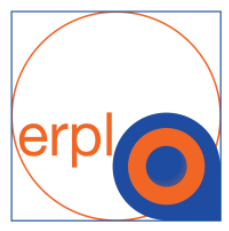


This text may be downloaded for personal research purposes only. Any additional reproduction for other purposes, whether in hard copy or electronically, requires the consent of the author. If cited or quoted, reference should be made to the full name of the author, the title, the working paper or other series, the year, and the publisher.

ISSN 1725-6739

(C) 2015 Norbert Reich

Printed in Italy

European University Institute

Badia Fiesolana

I-50014 San Domenico di Fiesole (FI)

Italy

www.eui.eu

cadmus.eui.eu 


\section{European Regulatory Private Law: The Transformation of European Private Law from Autonomy to Functionalism in Competition and Regulation (ERPL)}

A 60 month European Research Council grant has been awarded to Prof. Hans-Wolfgang Micklitz for the project "European Regulatory Private Law: the Transformation of European Private Law from Autonomy to Functionalism in Competition and Regulation" (ERPL).

The focus of the socio-legal project lies in the search for a normative model which could shape a selfsufficient European private legal order in its interaction with national private law systems. The project aims at a new-orientation of the structures and methods of European private law based on its transformation from autonomy to functionalism in competition and regulation. It suggests the emergence of a self-sufficient European private law, composed of three different layers (1) the sectorial substance of ERPL, (2) the general principles - provisionally termed competitive contract law - and (3) common principles of civil law. It elaborates on the interaction between ERPL and national private law systems around four normative models: (1) intrusion and substitution, (2) conflict and resistance, (3) hybridisation and (4) convergence. It analyses the new order of values, enshrined in the concept of access justice (Zugangsgerechtigkeit).

The research leading to these results has received funding from the European Research Council under the European Union's Seventh Framework Programme (FP/2007-2013) / ERC Grant Agreement n. [269722].
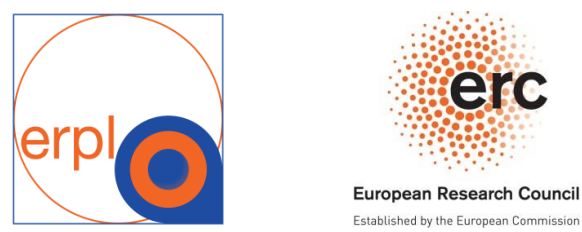


\section{Author Contact Details}

Prof. Dr. Dr. h.c. mult. Norbert Reich

Emeritus Professor of Private law and European Economic Law

University of Bremen

Email:n.reich1@gmx.net 


\begin{abstract}
The paper discusses the - seemingly successful - actions of German consumer associations against unjustified gas price increases by the dominant suppliers of so called "special clients". The clauses in the standard contract terms of the suppliers were condemned either as intransparent or/and as unfair by the German Federal Court (Bundesgerichtshof - BGH), supported and extended by the well-known $R W E$ judgment of the CJEU of 21.3.2013 ruling on the scope of Dir. 93/13/EEEC on un fair terms in consumer contracts. However, the actions of individual consumers for getting their money back after having been illegally overcharged have proven to be much more difficult because of a number of restrictive conditions imposed on restitution by the $\mathrm{BGH}$ which, in the opinion of this author, clearly violate EU law but have not yet been up to scrutiny before EU jurisdictions. The author makes a number of suggestions in this direction to help consumers, based on EU and/or corresponding German law, in particular Art. 47 of the EU Charter of Fundamental Rights.
\end{abstract}

\title{
Keywords
}

unfair terms in consumer contracts, principle of transparency, effects of intransparent terms, restitution in favour of overcharged consumers, restrictive conditions, violation of the EU-effectiveness principle of Art. 47 of the EU Charter of Fundamental Rights. 


\section{Table of Contents}

"I want my money back" - focusing the problems for German consumers in the liberalised energy market for natural gas

"We understand you want your money back" - reactions of the BGH to unilateral price increases based on standard forms of gas suppliers

"EU law helps you to get your money back" - the RWE judgment of the CJEU of 21.3.2013

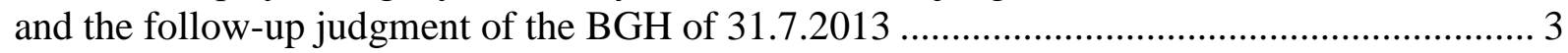

"I should get my money back - but I don’t get it!"........................................................... 4

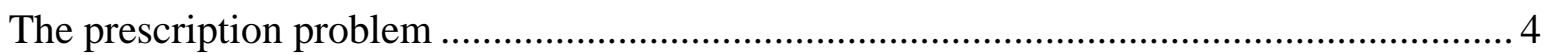

The limits of revision of unfair terms - the problematic theory of "ergänzende

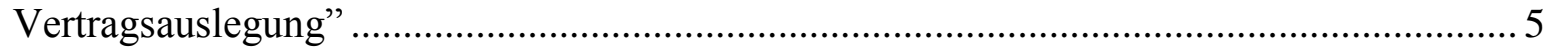

What happens if no price increase clause was included in the supply contract - the strange

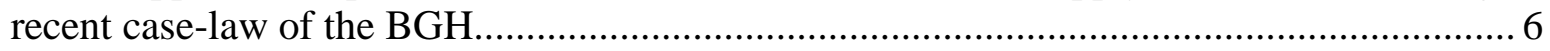

"I have a right to get my money back" - is the EU-effectiveness principle of help to the individual consumer or to collective consumer protection? ............................................... 7

The eliminatory function of the effectiveness principle - the problem of prescription ......... 8

The hermeneutical function of effectiveness - no "revision" of unfair clauses..................... 8

The remedial function of effectiveness - "Folgenbeseitigung" .......................................... 9

"I got my money back" - with the help of Verbrauchenzentrale (VZ) Hamburg .................... 10

The action for a declaratory judgment (Feststellungsklage) of 54 refusing customers supported by the VZ Hamburg against E-ON before the Landgericht (LG) and OLG

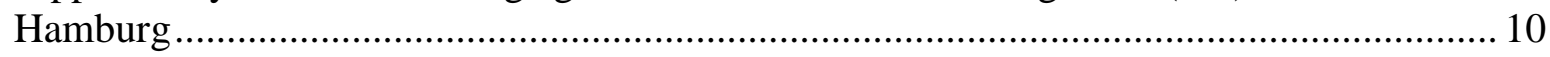

Injunctive relief sought against Vattenfall ........................................................... 11

"How can all of us get their money back?" - Future Prospects ............................................ 12 


\section{"I want my money back"- focusing the problems for German consumers in the liberalised energy market for natural gas}

The liberalisation of the energy market - in our case: the market for natural gas - has seen a dramatic regulatory shift from public to private law instruments. Price and service controls were abolished, supply organised via contract law under the (limited) freedom of contract principles following the impact of EU law. In the German context, the general contract law provisions of the BGB will apply to stop unilateral abuses of the market power of energy suppliers, usually monitored via the fairness and transparency control of general contract terms as written now into $\S 307-311$ BGB; a special provision of $\S 315$ allows a so-called "Billigkeitskontrolle" of unilateral price clauses of providers based on grounds of equity but will not be considered here in detail and only when necessary. Abuses of market dominant positions of suppliers are subject to German competition law ( $\S 19 \mathrm{GWB}$ ) and were before the Bundesgerichtshof (BGH - Federal Court) but remained without any impact on the market. ${ }^{1}$

Contract law had to take over market regulatory functions because of the wave of complaints by German consumers against in their opinion unjustified price increases supported and in many cases managed by German consumer advice centres (Verbraucherzentralen - VZ), in particular those active in Hamburg and Nordrhein-Westphalen (NRW). A certain "Europeanisation" of these complaints involved the CJEU in the famous RWE litigation brought by the VZ NRW for 25 individual consumers $^{2}$ based on the Unfair Terms in Consumer Contracts Directive 93/13 (UTCCD); this litigation was commented extensively in legal writing, including this author (with Hans Micklitz) ${ }^{3}$.

For consumers the litigation turned around the central question: "I want my money back" because of being overcharged by in their opinion unjustified price increases, paraphrasing the famous political claim of Premier Thatcher to get a special "British" rebate of its contributions to the EU. Of course, the amount of overcharging of the individual consumer does not come close to the size of the UK rebate - the $R W E$ litigation involved only a total sum of $16.128,63 €$ plus interest for alleged overcharges in the years 2003-2005, but the aggregate money of several hundred thousand of consumers involved ${ }^{4}$ is not far away from the British rebate which led the gas suppliers to ask for protection against these allegedly ruinous demands both by the Bundesverfassungsgericht ${ }^{5}$ and the CJEU. ${ }^{6}$ This was rejected by both jurisdictions despite their known disagreement about who takes "Kompetenz-Kompetenz" in EU matters.

To put new light into the litigation and to allow some generalisations for pricing policy in the EU energy market by looking at the deregulated German market the paper will proceed as follows:

\footnotetext{
${ }^{1}$ BGH, judgment of 29.4.2008, KZR 2/07, NJW (Neue Juristische Wochenschrift) 2008, 2172; the case was decided on contract, not competition law, see see the interesting study by Derleder, Der Stopp der Gaspreiserhöhungen durch die Zivilrechtsprechung - Vorstellung und Analyse eines wundersamen Eingriffs; KJ (Kritische Justiz) 2010, 292 at 297.

${ }^{2}$ Case C-92/11 RWE v Verbraucherzentrale NRW, judgment of 21.3.2013, opinion of AG Trstenjak of 13 September 2012

${ }^{3}$ H.-W. Micklitz/N. Reich, Von der Klausel- zur Marktkontrolle, EuZW 2013, 457; M. Fornassier, Der EuGH und die Kontrolle missbäuchlicher Klauseln: ein Kurswechsel?, ZEuP 2014, 410; E. Terryn, Unfair Contract Terms - Statutory Provisions, Price Increase Terms and the Role of the CJEU, in: Liber amicorum J. Stuyck, 2013, 677.

Büdenbender, Neugestaltung von Preisanpassungsklauseln in Energielieferungsverträgen über Elektrizität und Gas, NJW 2013, 3601 at 3607 talks of 13 million consumers concerned; of course not all had contracts with RWE. There is no precise statistical data available of the number of consumers overcharged by the different German energy suppliers.

${ }^{5}$ BVerfG, 2 chamber, order of 7.9.2010,1 BvR 2160/09, NJW 2011, 1339, insisting on the importance and limits of private autonomy in the energy sector.

${ }^{6}$ CJEU RWE para 62; similar AG Trstenjak at para 100.
} 
- Sec. 2 will briefly summarise the case law of the BGH which led to the reference to the CJEU and to its judgment of 21.3.2013;

- Sec. 3 will analyse the follow-up judgment of the BGH of 31. July 2013;

- Sec. 4 will describe the civil law problems of German consumers to "get their money back" after the successful $R W E$ and similar litigations;

- Sec. 5 will add some more general reflections on the use and the usefulness of (German and EU) civil law remedies for solving collective consumer problems like unjustified gas price increases.

- Sec. 6 takes a slightly empirical look at the activities of VZ Hamburg to help consumers which have served as a model for other regional VZ.

- Sec. 7 will add some legal policy considerations.

\section{"We understand you want your money back" - reactions of the BGH to unilateral price increases based on standard forms of gas suppliers}

The RWE litigation before German courts started in 2006, was referred to the CJEU on 9.2.2011 by the $\mathrm{BGH}^{7}$, lead to the judgment of the CJEU of 21.3.2013 and the final follow-up judgment of the BGH of 31.7.2013 ${ }^{8}$, conforming with the CJEU under the principle of "directive conforming interpretation."

Before this European litigation started, a great number of cases brought by VZ either in the name of individual consumers as representative (opt-in) actions, or as abstract injunctions before regional courts (LG = Landgerichte) according to Dir. 98/27 (now 2009/22/EC) ${ }^{9}$ were appealed to the competent Oberlandesgerichte (OLG) and finally to the Bundesgerichtshof (BGH) as highest instance in civil law matters where a more and more critical attitude towards unilateral prices increases in socalled special customer contracts (Sonderkundenverträge) could be observed. This led Professor Peter Derleder to state in 2010 which has not changed since: "No gas supplier to private household customers used an effective contractual price adaption clause ${ }^{10}$." He defines the case law of the BGH as "verbraucherrechtlich aufgeladene Machtbeschränkung" (consumer law imposed limitation of power) ${ }^{11}$. Just to mention some signposts of the case law without going into details which follow a sort of legal ping-pong: the supplier formulates unilateral price increase clauses, which by are attacked by a VZ either by a collective injunction or via a representative action in the name of individual consumers and supported by the BGH:

- Earlier litigation concerned the so-called "Ölpreisbinding" allowing an adaption of the wholesale price for natural gas depending on the price for raw oil; these clauses were condemned in a litigation under anti-trust law but decided under contract law in $2008^{12}$.

- Judgments of $15.7 .2009^{13}$ rejected the price adaptation clause of a gas supplier because it only regulated price increases, not - as a requirement of contractual fairness and balance - price

\footnotetext{
${ }^{7}$ VIII ZR 162/09, WM 2011, 850, citing different opinions in the literature. The order for reference seeems to be satisfied that the reference to the specific regulations for legal clients (Tarifkunden) are also applicable for special clients (Sonderkunden) - an opinion which was expressly rejected by the CJEU in its $R W E$ judgment. The transparency requirements should be interpreted „lighter“ (lockerer) for gas price increase clauses - a somewhat surprising opinion in contrast to its earlier case law and rejected by the CJEU and the follow-up judgment of the BGH of 31.7.2013.

${ }^{8}$ BGH VIII ZR 162/09, NJW 2013, 3647.

${ }^{9}$ For an overview see the EUI PhD thesis of Magdalena Ogorzalek, "The Action for Injunction in EU consumer law", 2014; also Reich, in Micklitz et al., European Consumer Law, $2^{\text {nd }}$ ed. 2014, para 8.33.

${ }^{10}$ At p. 293

${ }^{11}$ At p. 305

12 Supra note 1; comment Derleder at pp. 295.

${ }^{13}$ BGH, VIII ZR 225/07 NJW 2009, 2663, VIII ZR 56/08, NJW 2009, 2667
} 
decreases made possible by lower whole-sales costs of the supplier which should be passed on to the consumer

- Later judgments of $24.3 .2010^{14}$ rejected price index clauses linking the increase to general cost of supply or living without any specification; these new clauses were a direct result of the earlier BGH judgments.

- The judgment of $14.7 .2010^{15}$ introduced a new differentiation:

- Price increase clauses in the general contract conditions of gas suppliers were ineffective from 1.4.2007 on because of their intransparency if they did not specify the reasons and the criteria of a price increase.

- Similar clauses used in contracts before 1.4.2007 would be valid if they referred to the regulation of $\S 4 \mathrm{AVBGasV}$-a reference later condemned by the CJEU judgment of 21.3.2013.

As a result of this protracted litigation, the action of VZ NRW which concerned price increases before 1.4.2007 would have to be rejected - had it not been the reference to the CJEU by the same BGH of 9.2.2011 and its follow-up RWE judgment of 31.7.2013.

The most recent judgment of the BGH of 3 December $2014^{15 a}$ concerned an - unopposed - increase of gas-prices over a longer period of time without any basis in the contract - a judgment to be critically discussed later (see IV 3).

\section{"EU law helps you to get your money back" - the $R W E$ judgment of the CJEU of 21.3.2013 and the follow-up judgment of the BGH of 31.7.2013}

After the CJEU had condemned the price increase clauses in the general contract conditions for special clients (Sonderkunden based on the principle of private autonomy) of RWE both because of the ineffective reference to the German gas regulations ${ }^{16}$ and their missing transparency, the follow-up judgment of the BGH of 31.7.2013 could have limited itself to simply drawing the consequences for the German interpretation of $\S 307$ BGB on unfair general contract terms. The BGH expressly abandoned its earlier case law on the reference clause. It also gave lengthy and in my opinion an unnecessary and "intransparent" summary of its case law which had lead to the reference to the CJEU. It correctly applied the theory of directive conforming interpretation (para 56), it reminded the reader that it had interpreted the transparency requirement already in a similar way as that of the $R W E$ judgment (para 59), ${ }^{17}$ and that the voided clause could not be revised so to make it conforming with legislation (no "geltungserhaltende Reduktion" via "ergänzende Vertragsauslegung", para 62) ${ }^{18}$. It didn't say much about the right of restitution of overcharged consumers ${ }^{19}$, but it reminded them of the duty to expressly protest against unjustified price increases (para 64) - a somewhat strange obligation

\footnotetext{
14 BGH VIII ZR 178/06), WM (Wertpapiermitteilungen) 2010, 1044 (injunction), VIII ZR 304/08, WM 2010, 1050 (individual action)

${ }^{15}$ BGH VIII ZR 246/08, NJW 2011, 50

${ }^{15 a}$ BGH VIII ZR 370/13 not yet reported.

${ }^{16}$ The opinion of AG Wahl of 8 May 2014 in joined cases A. Schulz et al v TWS et al., C-359/11 and C 400/11 upheld this reference in standard contracts of gas clients because there is no freedom of contract. The CJEU in its judgment of 23 October 2014 did not follow the opinion of AG Wahl and condemned the clauses as intransparent against the relevant EU Gas Directive 2003/55.

${ }^{17}$ Why did it make the reference anyhow? See fn 7.

${ }^{18}$ Critique Büdenbender supra note 4 at p. 3603 referring to other BGH judgments where this method was expressly used for „saving“ unfair terms referring to judgment of 14 March 2012, VIII ZR 113/11, NJW 2012, 1865; 23.1.2013, VIII ZR 80/12, NJW 2013, 991.

${ }^{19}$ Büdenbender at p. 3606-3607 pointing to the limits of restitution under German law.
} 
imposed on consumers via "ergänzender Vertragsauslegung" (supplementary contract interpretation, critique under IV 2). ${ }^{20}$

The judgment lets the observer quite puzzled because it granted the 25 consumers represented by VZ NRW a nice restitution of about $650 €$ each (with a differentiation depending on the individual contract situation) but didn't help the hundreds of thousand consumers overcharged between 2003 and 2006, probably also later before the eventual formulation of new valid price increase clauses after the end of the litigation.

\section{"I should get my money back - but I don't get it!"}

The result of the $R W E$ litigation is quite absurd: a victory for some consumers and their representatives, but only for those few which dared to go to court and find support by VZ. This has been frequently argued against the uneven distribution paradigms of consumer policy: "Why the Haves Come out Ahead" (Marc Galanter) contrasted and at the same time supported by "Why the Poor Pay More" (David Caplovitz). In a worrying way, the German litigation on gas price increases seems to exactly follow this scheme, paraphrasing somewhat polemically Ms. Thatcher: I should get my money back - but I don't get it!

Just to list some of the reasons for this paradox:

\section{The prescription problem}

If, as in the $R W E$ case, a term on price increases has been found unfair and therefore is "not binding" on the consumer, the latter has a right under the German law of unjust enrichment ( $\S 812$ et seq. BGB) of restitution of money paid without justification, e.g. if a price acceleration clause has been rendered void; the German doctrine of unjust enrichment applies. The CJEU and in the follow-up judgment of 31.7.2013 the BGH rejected the former German practice of being satisfied with a reference to a statutory term in a parallel but identical setting. It considerably narrowed the scope of Art. 1 (2) of the UTCCD excluding the unfairness test for terms "reflecting mandatory statutory or regulatory provisions" of national law. The consumer is entitled to restitution of money which he needed not to pay, and the supplier must return the overcharge to which he was not entitled. The success of this type of unjust enrichment action depends on national law. The Court however has insisted in several judgments like Invitel ${ }^{21}$ that the national court has to draw "all the consequences (italics NR) that follow under national law, so that the consumer is not bound by that term". This of course includes restitution in full, not only in part.

The question now before national (German) courts, which has not yet reached the CJEU, is whether this EU right to restitution can be restricted by national prescription rules, that is to say can be reduced to a considerable extent by national rules which make part of the claim subject to prescription. This is a problem of German law on restitution of overcharged consumers in energy supply contracts. The conflict and the circumstances are of paradigmatic importance for the impact of EU civil law on national prescription rules and more broadly on the potential effects of a void term and the chances and opportunities not only to improve the future protection of consumers but to compensate them for financial loss in the past.

\footnotetext{
${ }^{20}$ For a general critique of this approach see the paper by Micklitz/Reich: Luxemburg ante portas - jetzt auch im deutschen "runderneuerten" AGB-Recht?, in: Festschrift U. Magnus, 2014, 631.

${ }^{21}$ CJEU case C-472/10, Nemzeti Fogyaszróvédelni Hatóság v Invitel , judgment of 26.4.2012 para 43.
} 
The BGH, in a continuous but not uncontested case law ${ }^{22}$ held that prescription starts with the date of the final yearly "Abrechnung" (settlement). Therefore, the prescription period for claims of restitution does run not from the date when the illegality has been firmly established in legal proceedings, but from the much earlier date when an "average consumer" could have brought a claim after having received the final settlement of his account, even if there is a risk that the contested term is upheld in later proceedings as not being unfair. This case law puts the risk of declaring a term to be void or not entirely on the consumer; the supplier will profit from lengthy proceedings, unless the consumer has taken the initiative to take his claim to court or simply refused to pay. According to information relating to Germany from consumer advice centres (VZ), only a small minority of consumers concerned will take the chance of bringing proceedings in an unsettled legal issue; the great majority will abstain, but run the risk that part of their claim will be prescribed once the final judgment on the illegality of the clause has been handed down. In the $R W E$ case, proceedings lasted about 7 years before the price increase clauses were finally declared to be illegal: due to the 3 year prescription period in German civil law ( $§ 195$ BGB) more than half the money paid by the "silent majority" of the gas supplier's clients did not need to be refunded.

\section{The limits of revision of unfair terms - the problematic theory of "ergänzende Vertragsauslegung"}

There is another impediment for full compensation in cases like RWE: In the opinion of the CJEU, the consequences of unfair terms are completely harmonized in Article 6 UTCCD, which means that courts may not revise a term so that it fits the fairness and good faith criteria, even if this could be possible under the minimum harmonization concept. This means, for instance, that a penalty clause which is excessive, cannot be reduced to an acceptable level, but is simply void and cannot be enforced any more against the consumer ${ }^{23}$. The CJEU wishes to avoid writing an unfair term being "risk free" for the supplier, if revision were allowed by "contributing to eliminating the dissuasive effect on sellers or suppliers of the straightforward non-application with regard to the consumer of those unfair terms...."

For German unfair contract term law the question arises whether the practice of the BGH to modify contested clauses by the method of "ergänzende Vertragsauslegung" (supplementary interpretation of the contract) according to a hypothetical will under the principle of good faith ( $\$ 157$ BGB) of the parties is compatible with the strict verdict of the CJEU, which precludes revision of clauses by courts. The $\mathrm{BGH}^{24}$ uses this method when, in its opinion, the nullity of the clause would lead to "unacceptable economic consequences" for the supplier, e.g. in long term energy supply contracts. The BGH wishes to protect the business model of the supplier, even if the terms of the conditions for price modifications have been declared unfair. So far, the BGH has refused to make a reference to the CJEU on this issue because of the - in its opinion - substantial difference between a revision of a clause and its "mere" amendment by way of interpretation. However, this argument does not seem convincing because ultimately the BGH does what has been expressly forbidden by the CJEU: it rewrites and revises the contract without any clear legislative reference, and thereby endangers the very principle of transparency. Again, the supplier can use "risk free" an unfair term by relying on the power of the courts to modify it to an "acceptable, fair" level under an alleged hypothetical will of the parties.

\footnotetext{
${ }^{22}$ BGH, 23 May 2012, VIII ZR 210/11, NJW 2012, 2647; 12 Jan. 2013, VIII ZR 80/12, NJW 2013, 991; in banking law, the BGH in its judgment of 20.10.2014 cases XI ZR 348/13 + 417/14 concerning consumer credit fees has taken a different view.

${ }^{23}$ CJEU, case C-618/10, Banco espanol de Credito/Camino [2012] ECR I-(14.6.12) paras 53-54; for an overview of the new case law of the CJEU see Micklitz/Reich, The Court and the Sleeping Beauty - The Revival of the Unfair Contract Terms Directive, CMLRev 2014, 771 at 792. For a recent restatement see opinion of AG Wahl of 16 October 2014 in joined cases C- 484/13 et seq. at para 26.

${ }^{24}$ Supra note 18 .
} 
This method has been used by the BGH to impose on the consumer a duty to protest expressly against a price increase within a three year period after the final settlement; if he does not do so the claim to restitution will be unenforceable, whether prescribed or not. ${ }^{25}$ It has however not been possible despite such attempts by the suppliers - to completely rewrite the incriminated price increase clause as such - an attempt expressly rejected by the $\mathrm{BVerfG}^{26}$.

\section{What happens if no price increase clause was included in the supply contract - the strange recent case-law of the BGH}

The most recent BGH judgment of 3.12.2014 in the gas-price litigation saga concerned an individual litigation where the plaintiff, over a period of more than a year between 2007 and 2008), paid a price well beyond the original price without the contract containing any price increase clause. Only in 2011 he reclaimed the price increase as unjustified and wanted reimbursement of the overcharge of about $1500 €$. The BGH did not itself decide the matter itself but remanded the case back to the Landgericht Potsdam where it is pending now for final judgment; the plaintiff will be asking for a reference of the case to the CJEU on the problem of the legality of the price increase which the BGH seems to take as justified under German unfair terms law; it does not mention EU law, in particular Dir. 93/13 and the prior $R W E$ judgment.

The BGH repeats and extends its above mentioned and criticised theory of "ergänzende Vertagsauslegung" to cases where the consumer has not raised in time an opposition to the price increase. This is said to be the case also where a "pre-formulated right to price increases has not been effectively included in the contract" (ein formularmäßiges Preisanpassungsrecht (ist) nicht wirksam in den Vertrag einbezogen worden.., $\$ \$ 305(2), 307$ (1) $1^{\text {st }}$ para BGB).

The BGH justified this surprisingly short statement with two arguments:

- The more formal one extends the theory of a gap in the (gas supply) contract which must be closed by reference to "ergänzende Vertragsauslegung", based on the principles of good faith and hypothetical will of the parties. This is justified by the general clauses of the BGB of $\S \S 133$, 157.

- The substantive argument is concerned with the balancing of interests in long-term contracts. The Court writes:

"bei langfristigen Vertragsverhältnissen besteht ein anerkennenswertes Bedürfnis der Parteien, das bei Vertragsschluss bestehende Verhältnis von Leistung und Gegenleistung über die gesamte Vertragsdauer im Gleichgewicht zu halten.

Diesem Bedürfnis liefe es zuwider, wenn bei einem Energielieferungsvertrag mit langer Laufzeit die Unwirksamkeit von Preiserhöhungen rückwirkend ohne zeitliche Begrenzung geltend gemacht werden könnte. Denn dies hätte zur Folge, dass der Energieversorger ohne Rücksicht auf Schwankungen seiner eigenen Bezugspreise für die gesamte Vertragslaufzeit nur den ursprünglich vereinbarten Preis beanspruchen könnte. Angesichts der Entwicklung der Energiepreise entstünde dadurch bei langfristigen Versorgungsverträgen regelmäßig ein gravierendes Ungleichgewicht von Leistung und Gegenleistung. Dies wäre unbillig, würde dem Kunden einen unverhofften und ungerechtfertigten Gewinn verschaffen und entspräche auch nicht dem objektiv zu ermittelnden hypothetischen Parteiwillen" (para 27).

(In case of a long-term contractual agreement there is a recognised need of the parties, to keep balanced the original relation between supply and demand prices over the entire term of the contract. It would be in opposition to that need if the ineffectiveness of a price increase in an energy delivery contract could be invoked backwards without any time limitation. This would lead to the consequence that the energy supplier could only demand the original price without

\footnotetext{
${ }^{25}$ Critique Micklitz/Reich, supra note 20 at p. 635.

${ }^{26}$ Supra note 5.
} 
adaption to changes in his own supply prices. Due to the development of energy prices this would cause a serious imbalance between the prices for supply and demand in long term contracts. This would be unfair because it would give the client an unexpected and unjustified profit not conforming to the hypothetically interpreted will of the parties) (translation NR).

The court however declines to define the criteria of an ex-lege price adaptation based on equity reasons but simply refers to the requirement of the consumer to oppose the price increase within a time limit of three years after the last settlement. In the present case the consumer raised his opposition seemingly too late and therefore could not claim back the overcharge.

The argument of the judgment leaves the observer puzzled:

- It is somewhat surprising to extend the theory of "ergänzende Vertragsauslegung" as developed in the case of an unfair or intransparent contract clause to the different case where no such clause has been imposed by the supplier at all. Isn't it the responsibility of the supplier under freedom of contract principles to secure his rights by drafting respective contract terms? Why should the judge help the supplier to rewrite his contracts? By avoiding any price increase clauses the supplier shields itself against a later challenge of this clause as under the $R W E$ litigation

- How can the general transparency principle as element of contractual information be fulfilled by non-information? ${ }^{25 a}$ Shouldn't the transparency requirement of Art. 4 (2), 5 Dir. 93/13 be read as the general requirement to prior information concerning contract prices and their eventual increases? Isn't the logical consequences of such a missing clause that the supplier cannot enforce any price increase - "too bad for him" but part of his freedom of contract as guaranteed by Dir. 93/13?

- Recital 20 requires that "contracts should be drafted in plain, intelligible language, the consume should actually be given the opportunity to examine all the terms ...". How can the consumer "examine" a term which was not been included in the contract and only later imposed by the case-law of the BGH?

\section{"I have a right to get my money back" - is the EU-effectiveness principle of help to the individual consumer or to collective consumer protection?}

Can the seemingly contradictory results of the litigation of consumers and VZ against gas suppliers be remedied under EU law, after German law under the interpretation of the BGH seems to rule that out, at least for gas price increases 3 years before the last settlement of the account. But even within this narrow period the consumer must expressly protest within a three year period.

Can the effectiveness principle under Art. 47 (1) Charter/19 (1) sentence 2 of the TEU be of help? Article 47 of the Charter says:

Everyone whose rights and freedoms guaranteed by the law of the Union are violated has the right to an effective remedy before a tribunal in compliance with the conditions laid down in this Article.

In a sort of follow-up, Article 19(1) s. 2 TEU puts the responsibility for "providing remedies sufficient to ensure effective legal protection in the fields covered by Union law" on Member States through the status of their courts of law as "Union courts." I have tried to show in a different context that the term "sufficient remedies" means "adequate remedies", not just minimum protection which must be provided by national law. ${ }^{27}$ If national law does not meet these standards, there are three methods available under EU law to "upgrade" national remedies which in our case will attain a sort of "hybrid

\footnotetext{
${ }^{25 a}$ Micklitz/Reich, supra note 3 at p. 460: „Transparenz durch Information“; Micklitz in: European Consumer Law, supra note 9 at paras 3.16-3.18.

${ }^{27}$ Reich, General Principles of EU Civil Law, 2014, Chapter IV, para 4.10.
} 
status" between German and EU law. I have called these three methods or functions of the effectiveness principles:

- the eliminatory function

- the hermeneutical function

- the remedial function

I will demonstrate the consequences of this approach in the context of the $R W E$ litigation:

\section{The eliminatory function of the effectiveness principle - the problem of prescription}

The eliminatory function of the effectiveness principle as developed already in early CJEU case law concerns in particular the restrictive German prescription rules ${ }^{28}$. As a general principle, such rules on prescription are subject to national law, but must still meet the requirements of effectiveness and equivalence. Effectiveness in this context means that national law may not make (full!) restitution practically impossible or excessively difficult. There is some case law of the CJEU concerning the working of prescription rules on citizens' rights established under EU law. As a general rule, the consumer (the client, worker) must have had a chance to know that his claim will be prescribed under applicable prescription rules ${ }^{29}$. In the German cases on restitution of overcharged energy prices the consumer did not know and could not reasonably have known whether and when the contested term would finally be declared to be void (or not!). The "average consumer" is not an expert. If the term has been annulled with definite effects, he is entitled to full, not just to partial compensation; a prescription period should only run from that date, not from an earlier date as in the case law of the BGH which applies the date of the yearly settlement ${ }^{30}$. If the final judgment on the illegality of the term was handed down in 2013 and the consumer received from RWE a yearly settlement statement, his claim for restitution under the case law of the BGH would be limited to the 3 year period between 2010 and 2012 and not go back till 2004/6. This means that he is deprived of more than half of his claim, as full compensation of that part is made practically impossible by the method of determining the prescription period in the case law of the BGH.

\section{The hermeneutical function of effectiveness - no "revision" of unfair clauses}

The hermeneutical function of the effectiveness principle ${ }^{31}$ is particularly important for criticising the attempt of the BGH to "save" unfair terms in long-terms contracts concerning price increase of energy supply. The BGH in effect rewrites the terms of a pre-formulated contract which makes the consumer remedy of restitution either ineffective or subject to additional requirements imposed ex post factum by imposing an express duty of opposition (Widerspruch) on the consumer ${ }^{32}$. The CJEU case law on prohibiting a revision of unfair terms has the objective of safeguarding consumer rights under the UTCCD which must be interpreted in conformity with the effectiveness principle. The BGH case law on "ergänzende Vertragsauslegung" is a clear violation of these principles ${ }^{33}$ unless it serves, as the CJEU in its Kásler judgment of 30 April $2014^{34}$ held, to improve or safeguard the position of the consumer vis-à-vis his contract partner.

\footnotetext{
${ }^{28}$ Reich at 4.3

${ }^{29}$ Case C-326/96 Levez v Harlow Pools [1998] ECR I-7835

${ }^{30} \mathrm{BGH}$ at fn 18

${ }^{31}$ Reich at 4.7

${ }^{32}$ Supra not 18; critique Reich/Micklitz surpa nto 20 at p. 635 ..

${ }^{33}$ For a different view see Büdenbender aupra note 4 at p. 3606: no control fo these clauses under EU law.

${ }^{34} \mathrm{C}-26 / 13$ at para 84
} 


\section{The remedial function of effectiveness - "Folgenbeseitigung”}

The remedial function of the effectiveness principle ${ }^{35}$ is certainly the most problematic one since, as a starting point, Member State and not Union law is to guarantee remedies "sufficient" for an effective enforcement of civil (consumer) rights. In the RWE case this concerns mostly collective remedies which seem to be absent in German law; each individual consumer who is complaining of an overcharge has to take his case against RWE eventually to court which - according to well known practice - rarely happens and leaves a remarkable windfall of illegal profits to RWE. This is quite in contrast to the principle of effective enforcement of consumer rights, including a certain deterrent effect. If the VZ takes its case by a representative action, it has to give detailed documentation of each consumer's case on an opt-in basis.

EU law cannot create a class or group action ex nihilo because of the so-called "procedural autonomy" of Member states. But there is another remedy already available in German law, namely the so-called "Folgenbeseitigungsanspruch" (claim by a consumer association to eliminate the negative consequences of an unfair commercial practice or clause by a duty to inform the public about the results of a lost ligation - similar to a recall action in product safety law ${ }^{36}$ which has been developed by the "Kammergericht" (appeal court) in Berlin ${ }^{37}$. Doesn't the effectiveness - taken together with the equivalence - principle require its being taken over to remedy the consequences of unfair contract terms like in the $R W E$ case? ${ }^{38}$

The so-called "Folgenbeseitigungsanspruch" under German UWG-practice does not give a direct remedy to the consumer against the undertaking acting unfairly, but only an obligation of the service provider to inform potential consumers that they may have been subject to unfair practices and that they should turn to an independent ADR- or similar entity to process their claim. This claim can be enforced by consumer associations competent to take injunctions according to EU Directive 2009/22. This remedy does not guarantee the consumer to get "his money back", but at least allows a procedure to make his claim known to the public where the injured consumer may be aware of having a claim against the overcharging gas supplier. Under Article 12 of the new ADR-Directive 2013/11 19 it would also have the effect of avoiding a prescription of claims if the claim is brought before an ADR entity. This procedure should be handled by a trustee without the need of protracted, individual and ineffective litigation which is now the case in Germany. Of course the above mentioned problems of prescription and contract revision would have to be settled by further references from German courts to the CJEU, following the $R W E$ precedent.

On the other hand, the famous US type class-action - which is not popular neither in the EU nor in Germany ${ }^{40}$ - would probably be of no help to remedy the situation of the individual consumer having been overcharged. The class action is possible under Rule 23 of the US Federal Rules of Civil Procedure where a single plaintiff or small group of plaintiffs seeks to proceed on behalf of an entire

\footnotetext{
${ }^{35}$ Reich at 4.10

${ }^{36}$ Hörmann, Unrecht ohne Folgen, VuR 2014, 245

${ }^{37}$ Unpubl. judgment of 27.3.2013, 5 U 112/11; similar now judgment of 7 August 2014 by Landgericht Stuttgart, 11 O 298/13.

${ }^{38}$ For a recent analysis see Reich, Zur Möglichkeit und Durchsetzung eines sog. Folgenbeseitigungsanspruchs im UWG- und AGB-Recht, VuR 2014, 247.

${ }^{39}$ Directive 2013/11/EU of the EP and the Council of 21 May 2013 on consumer ADR, OJ L 165, 18 June 2013, 63 Reich in Micklitz et al, supra note 9 at para 8.23a.

${ }^{40}$ See Commission recommendation of 11 June 2013, OJ L 260/60; Reich at para 8.44; Stadler, European Developments in Collective Redress, euvr (Europäische Zeitschrift für Unternehmens- und Verbraucherrecht, 2014, 80.
} 
class who have been harmed by the same conduct by the same defendants; the questions of law or of facts must be common to the class. Court approval is required for this procedure which follows an optout scheme but would probably not be granted for an action of restitution based on unjust enrichment. This "same conduct" would usually not be the case for an action in unjust enrichment of consumers being overcharged due to illegal price increases clauses. This exclusion is due - unlike in an action on compensation based on tort law - to the individual contract situation of consumers.

\section{"I got my money back" - with the help of Verbrauchenzentrale (VZ) Hamburg}

\section{The action for a declaratory judgment (Feststellungsklage) of 54 refusing customers supported by the VZ Hamburg against E-ON before the Landgericht (LG) and OLG Hamburg}

To see the difficulties of German consumers to get their money back and consumer advice centres (Verbraucherzentrale - VZ) to support them, it is useful to take a look at the activity of VZ Hamburg which has been particularly active and competent in this area. The situation which the writer could discuss with staff of the VZ was as follows:

After privatisation of the city owned supplier for natural gas in Hamburg during the turn of the millennium the new private supplier E-ON substantially increased its prices after 2000. A number of special customers whose contracts where in theory freely negotiated, that is, were governed by the rules of the BGB on unfair terms ( $\S 3307 \mathrm{ff}$.) and on unfair unilateral price determination ( $\S 315$ ) mentioned above, refused to pay the price increase; a civil society movement of opposition emerged ${ }^{41}$. E-ON first sued the "refusniks" for payment before several Amtsgerichte but lost most of its cases. VZ Hamburg supported an action of 54 clients in 2005 before the LG Hamburg, decided by judgment in favour of the clients only on 27.10.2009. The aim of the action was a binding declaration (Feststellungsklage) that the refusal of the represented clients was justified, that is E-ON could not sue them for payment. E-ON lost its appeal before the OLG Hamburg by judgment of 30.1.2013.

This is not the place to go into details of the rather protracted and lengthy proceedings. According to information collected with the help of VZ Hamburg, the action brought in 2005 was first based on $\S 315$ (3) BGB arguing that the unilateral price increase was unfair (unbillig). The LG Hamburg required an expert opinion of an economist who however could not determine the level of "fairness of pricing" because the supplier refused to disclose its price calculation as a "business secret".

VZ (or rather the individual plaintiffs) than decided to change the legal argument insisting on the unfairness and intransparency of the price increase clauses in the general supply terms of E-ON as such; once these clauses were regarded as void the resulting increases were without "legal reason" in the terminology of the German law of unjust enrichment ( $\$ 812$ BGB) and had to be paid back or - if consumers had refused to pay them, could not be claimed by legal action, which was exactly the objective of the declaratory action by VZ Hamburg.

The judgment of LG Hamburg of 27.10.2009 is particularly interesting in this regard because it anticipates to some extent the later argument of the CJEU in the RWE case. The incriminated clause simply said:

E.ON is entitled to adapt its prices to the development of pricing on the thermal energy market (E.ON .... ist berechtigt, ihre Preise der Preisentwicklung auf dem Wärmemarkt anzupassen).

LG Hamburg condemned this clause as unfair according to the German legislation on unfair terms ( $\S$ 307 (1) and (2) BGB) and following the more recent case law of the BGH which has been mentioned

\footnotetext{
${ }^{41}$ Derleder supra note 1 at pp. 292.
} 
above $^{42}$. The clause is both intransparent as not being clear and comprehensible, and it disadvantages in an unjustified manner (unangemessen) the consumers against the principles of good faith. There is no possibility to save the clause by "ergänzende Vertragsauslegung". This reasoning allowed the LG Hamburg to avoid the difficult problem of fixing a "fair price" according to $\S 315$ (3) BGB - a reasoning upheld by most German courts, including the $\mathrm{BGH}$ for the time being.

The judgment went in to some detail concerning the requirements of a "transparent" and "fair" price increase clause insisting on prior detailed information about reasons and criteria for price adaptations. An only indirect reference to $\S 4 \mathrm{AVBGas}$ and $\S 5 \mathrm{GasGVV}$ - in difference to the above mentioned BGH judgment of 13 June 2007 - does not fulfill the transparency requirement because these provisions have not been expressly included in the general conditions. Since they apply only to legal clients (Tarifkunden), not to special clients (Sonderkunden), they cannot be regarded as a legislative model of fairness.

The judgment of the OLG Hamburg of 30.1.2013 dismisses the appeal of E-ON with nearly the same reasoning as the LG Hamburg. It rejects later attempts of E-ON to impose a modified price increase clause on its customers as not being clear and specific enough. The supplier could have protected its business interests via a unilateral cancellation of the supply contracts which it hadn't done. The Court allowed an appeal to the Bundesgerichtshof which was not followed on.

As a result, the 54 (on appeal only 53) clients did not have to pay the price increases; the judgment was however without effect on the many other clients who "faithfully" paid their bills without protest. "Some clients got their money back" - the great majority didn't! And E-ON could happily keep its profits drawn from illegal price increase clauses; it only had to pay the legal bill and loose out on 54/53 clients who hadn't paid the increases anyhow. Attempts of the VZ Hamburg to spread the profit from this litigation to a great majority of consumers failed due to the intricacies of the German law on restitution which have been mentioned above.

The representative action of VZ Hamburg in support of opposing clients (Widerspruchskunden)

In a later representative action against E-ON brought by VZ Hamburg in 2009 sought payment of a total sum of $€ 86.652$ for about 55 individual clients who had assigned their claims by special documentation - an opt-in proceeding possible under German law of consumer protection. The LG Hamburg by judgment of 17.10.2011 awarded $75.314 €$, that is about an average of $€ 1.370$ for each client (even though the concrete accounts may have been quite different). These clients had paid their bills including price increases, but had expressly opposed payment according to the case law of the BGH on "ergänzende Vertragsauslegung".

E-ON used identical clauses as in the earlier litigation and amended them by a reference to $\S 4$ AVBGasV resp. $\S 5$ GasGVV. The LG avoided the clause because it contained only a unilateral right to price increase, not a corresponding right to a price reduction. A right to price adaptation does not follow from the reference to $\S 4$ AVBGasV resp. $\S 5$ GasGVV nor by revision of the entire contract via "ergänzende Vertragsauslegung". However, the overall sum of the claim was not justified; therefore the judgment reduced the claim by about $15 \%$.

E-On had taken the case on appeal to the OLG Hamburg but took it back after realising that it would not be successful.

\section{Injunctive relief sought against Vattenfall}

In 2014, the - successful - litigation strategy of VZ Hamburg was continued by an injunction (Unterlassungsklage) against the price increase clauses used by Vattenfall, another supplier of natural gas on the Hamburg energy market. These clauses are hardly different from the ones used and

\footnotetext{
${ }^{42}$ Supra note 1 (BGH NJW 2008, 2172).
} 
incriminated in the RWE case - VZ regarded this as an "easy" case. Since however Vattenfall did not agree to the "Abmahnung" (written formal warning) by the VZ to stop using its incriminated clauses, VZ had to take an action for an injunction before the LG Hamburg; the litigation is still pending but seems unproblematic on its merits after the most recent case law of the CJEU and the BGH.

It has been discussed by this author with lawyers of VZ Hamburg whether the action should be coupled with a special claim for a "Folgenbeseitigungsanspruch", that is a legally binding pronouncement by the court that Vattenfall must inform its customers of the eventual avoidance of its clauses and give them the possibility to claim restitution. However, the law on "Folgenbeseitigungsanspruch" has not yet been developed sufficiently clear; VZ would have to bring a test case which it might lose and therefore cause problems to its (rather limited!) litigation budget. But the discussion is still going on!

\section{"How can all of us get their money back?" - Future Prospects}

Under Art. 23 (1) of the new Consumer Rights Directive 2011/83 of 25 October $2011^{43}$, Member states are required to ensure that "adequate and effective means exist to ensure compliance with this Directive"; this includes enforcement under Dir. 93/13 which is part of the consumer acquis. This requires a closer linking of the different remedies available to consumers and consumer associations under EU and German law. I will give some first suggestions in this direction:

- A successful injunction in the public interest by a consumer association like a VZ should have third-party effects against the same supplier, benefitting all consumers in a similar situation. Such a remedy has been spelled out by the CJEU already in Invitel. ${ }^{44}$

- The action for an injunction should be coupled with a separate "Folgenbeseitigungsanspruch." Its legal basis and impact has to be worked out more precisely in German and EU law on unfair terms (Art. 6/7 Dir. 93/13).

- The final result of the injunction should be prejudicial to the follow-on claim for restitution either by individual consumers or by a representative action of a VZ (or both).

- The restrictive case law of the BGH on restitution, namely by its interpretation of the prescription provisions of the BGB and its use of the "ergänzende Vertragsauslegung" to require the consumer to take an express opposition to maintain its claim within a three year period after the "Abrechnung" (settlement), should be reconsidered under EU law, preferably by a separate reference to the CJEU similar to the $R W E$ litigation. This is possible against the $\mathrm{BGH}$ judgment of 3.12.2014, including to contest a price increase on equity grounds without any contractual basis.

\footnotetext{
43 [2011] OJ L 304/64; see already the Invitel-judgment, supra note 21 at para 35.

${ }^{44}$ Supra note 21 at para 38; Reich, supra note 27 at 4.16; Micklitz/Reich, supra note 23 at p. 794.
} 


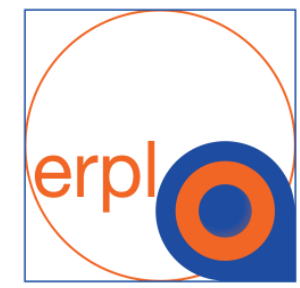

European Research Council Established by the European Commission

This EUI Working Paper is published in the framework of an ERC-funded project hosted at the European University Institute. 